\title{
Mutations in the K-ras Oncogene Induced by 1,2-Dimethylhydrazine in Preneoplastic and Neoplastic Rat Colonic Mucosa
}

\author{
Russell F. Jacoby, Xavier Llor, Ba-Bie Teng, Nicholas O. Davidson, and Thomas A. Brasitus
}

Section of Gastroenterology, Department of Medicine, The University of Chicago, Chicago, Illinois 60637

\begin{abstract}
These experiments were conducted to determine whether point mutations activating $\mathrm{K}$-ras or $\mathrm{H}$-ras oncogenes, induced by the procarcinogen 1,2-dimethylhydrazine (DMH), were detectable in preneoplastic or neoplastic rat colonic mucosa. Rats were injected weekly with diluent or DMH at $20 \mathrm{mg} / \mathrm{kg}$ body wt for $5,10,15$, or 25 wk, killed, and their colons dissected. DNA was extracted from diluent-injected control animals, histologically normal colonic mucosa from carcinogen-treated animals, and from carcinomas. Ras mutations were characterized by differential hybridization using allele-specific oligonucleotide probes to polymerase chain reaction-amplified DNA, and confirmed by DNA sequencing. While no $\mathrm{H}$-ras mutations were detectable in any group, K-ras (G to A) mutations were found in $66 \%$ of DMH-induced colon carcinomas. These mutations were at the second nucleotide of codons 12 or 13 or the first nucleotide of codon 59 of the $K$-ras gene. The same type of $K$-ras mutations were observed in premalignant colonic mucosa from 2 out of 11 rats as early as 15 wk after beginning carcinogen injections when no dysplasia, adenomas, or carcinomas were histologically evident, suggesting that ras mutation may be an early event in colon carcinogenesis. (J. Clin. Invest. 1991. 87:624630.) Key words: ras mutations • colon cancer $\bullet$ polymerase chain reaction $(\mathrm{PCR}) \cdot \mathrm{DNA}$ sequencing • oligonucleotide probe hybridization
\end{abstract}

\section{Introduction}

Colonic carcinogenesis appears to be a complex phenomenon, which proceeds through multiple stages, including initiation, promotion, and progression (1). Increasing evidence suggests that this multistage process may result from the accumulation of genetic alterations in certain protooncogenes or other genes, thereby leading to progressive disordering of the mechanisms that normally regulate cellular growth and differentiation (2). Sites of genetic alteration implicated in the development of human colonic neoplasia include the adenomatous polyposis coli locus on chromosome 5 , the p53 gene on chromosome 17 , and the "deleted in colorectal cancer" gene on chromosome 18 (3). Another genetic alteration suggested to be of importance in the pathogenesis of colonic malignant transformation is ras

Address reprint requests to Dr. Thomas A. Brasitus, The University of Chicago, Section of Gastroenterology, 5841 S. Maryland Avenue, Box 400, Chicago, IL 60637.

Received for publication 5 July 1990 and in revised form 20 September 1990

J. Clin. Invest.

(c) The American Society for Clinical Investigation, Inc.

0021-9738/91/02/0624/07 \$2.00

Volume 87, February 1991, 624-630 gene mutation $(4,5)$. H-ras, K-ras, or N-ras genes encode similar 21,000-D membrane-bound proteins with intrinsic GTPase activity that have a presumptive role in growth signal transduction (6). Single point mutations at specific sites within ras genes activate their oncogenic potential and such mutations have been observed in many human tumors (7), mcluding human colon carcinomas. K-ras mutations, for example, have been reported in $\sim 40-50 \%$ of these latter malignancies (3-5). Moreover, such mutations have also been detected in premalignant adenomas as well as in "normal" colonic mucosa adjacent to carcinomas, suggesting that these genetic alterations may be an early event in tumorigenesis of this organ (8).

In this regard, in recent years experimental models of carcinogenesis have been used to search for and elucidate the molecular mechanisms, such as ras protooncogene activation, involved in these multistage processes for many malignancies other than colon cancer (9). For example, experiments with the alkylating agent $N$-nitroso- $N$-methylurea have demonstrated that mammary carcinomas induced by this agent have $G$ to $A$ mutations at one specific site, the second nucleotide of codon 12 of the H-ras oncogene (10). These findings are of interest since this carcinogen generates the methylated adduct $O^{6}$ methylguanine which, if not repaired, may mispair with thymidine during DNA replication resulting in a G:C to A:T transition (11). Taken together, these results, therefore, strongly suggest a causal relationship between $N$-nitroso- $N$-methylurea administration, H-ras mutation, and the initiation of carcinogenesis. Moreover, the selective nature of these mutations may be related to site-specific differences in accessibility of the carcinogen to DNA, or alternatively to differential rates of formation and/or repair of these adducts, in addition to possible selection for particular amino acid substitutions in the ras protein $(12,13)$.

Based on the above observations, it is clear that the relationship between mutations in specific genes and the initiation of colon cancer should more easily be studied in experimental systems in which tumors are reproducibly induced and important etiologic, genetic, or dietary factors can be manipulated or controlled. Moreover, using such animal models, preneoplastic colonic mucosa can be obtained soon after carcinogen administration to detect the earliest possible molecular alterations, providing information regarding the order of occurrence of mutations in various genes. In this regard, an excellent experimental model of colon cancer is the induction of colon tumors in rodents by the administration of 1,2-dimethylhydrazine (DMH) ${ }^{1}$ or its metabolites azoxymethane or methylazoxymethane (14, 15). Colon carcinomas appear after a latency period of $\sim 6 \mathrm{mo}$ in almost all rats injected with the usual dosage schedule of $\mathrm{DMH}$, if the rats are from a susceptible strain (16). These tu-

1. Abbreviations used in this paper: $\mathrm{DMH}, 1,2$-dimethylhydrazine; PCR, polymerase chain reaction. 
mors closely parallel human colonic neoplasia in clinical and pathologic features (15-18). An initial indication that the Kras oncogene may be activated by $\mathrm{DMH}$ in these tumors was previously obtained by Caignard and colleagues using the $\mathrm{NIH} / 3 \mathrm{~T} 3$ transformation assay (19); however, these investigators did not determine whether these mutations are frequent events and did not characterize any specific point mutations. The spectrum of mutations (site and type of nucleotide substitution) is important because it may provide evidence for particular mechanisms of mutagenesis (13). In these experiments we, therefore, investigated the pattern of mutations induced in the $\mathrm{H}$-ras or K-ras oncogenes by 1,2-dimethylhydrazine in rat colon carcinomas and premalignant carcinogen-treated colonic mucosa, to provide information regarding the mechanism of activation of the ras oncogene by this carcinogen, and to determine whether these mutations are an early event in colon carcinogenesis. The results of these studies as well as a discussion of their relevance to colonic malignant transformation in this model serve as the basis for this report.

\section{Methods}

Materials. Thermus aquaticus (Taq) DNA polymerase was obtained from Perkin-Elmer Cetus (Norwalk, CT). dATP, dCTP, dGTP, and dTTP, and $\mathrm{T}_{4}$ polynucleotide kinase were obtained from Pharmacia Fine Chemicals (Milwaukee, WI). Tetramethyl ammonium chloride was obtained from Fluka Chemical Corp. (Ronkonkoma, NY). Nitrocellulose $0.2-\mu \mathrm{m}$ membranes and the Minifold II slot blot apparatus were obtained from Schleicher \& Schuell, Inc., (Keene, NH). Salmon sperm DNA and 1,2-dimethylhydrazine were obtained from Sigma Chemical Co. (St. Louis, MO). [ $\gamma^{32}$ P]ATP was obtained from New England Nuclear (Boston, MA). Anion-exchange columns (Qiagen tip5) were purchased from Qiagen Inc. (Studio City, CA) and solid phase extraction columns (Sep-Pak $\mathrm{C}_{18}$ cartridges) were obtained from Waters Associates, Millipore Corp. (Milford, MA). Sequencing reaction products (sequencing buffer, DTT, manganese buffer, Sequenase enzyme, ddG, ddA, ddT, ddC termination mixtures) were obtained from United States Biochemical Corp. (Cleveland, OH). Compounds for the sequencing gel were purchased from National Diagnostics, Inc. (Manville, NJ). The other reagents were of the highest commercially available grade.

Colon carcinogenesis. Male albino Sherman rats initially weighing $\sim 100 \mathrm{~g}$ were given subcutaneous injections of either diluent or 1,2-dimethylhydrazine at a dose of $20 \mathrm{mg} / \mathrm{kg}$ body wt per wk for $5,10,15$, or $25 \mathrm{wk}$. The stock solution for injections consisted of DMH dissolved in $100 \mathrm{ml}$ water containing $37 \mathrm{mg}$ EDTA and was adjusted to $\mathrm{pH} 6.5$ with sodium hydroxide. The animals were maintained on a pelleted diet (Purina rat chow from Ralston-Purina Co., St. Louis, MO) with water and food ad lib. in standard cages. 1 wk after the last DMH injection, the animals were killed by halothane inhalation and their colons excised. Gross tumors were identified, their size and location in millimeters from the anus were recorded, and the tumors were carefully dissected from each colon. Tissue specimens $\sim 1-2 \mathrm{~mm}^{2}$ in area were taken from control colonic mucosa, from normal preneoplastic colons after 5,10 , or $15 \mathrm{wk}$ of carcinogen treatment, and from carcinomas or "uninvolved" proximal and distal colon after 26 wk of DMH treatment, and were frozen quickly in liquid nitrogen for subsequent DNA extraction. Portions of these specimens were also preserved in formalin for histopathologic examination as previously described (20).

Oligonucleotide synthesis and preparation. Oligonucleotides, for use as "amplimers" or probes, were synthesized on a 380B synthesizer (Applied Biosystems, Inc., Foster City, CA) for rat K-ras (Table I) and rat $\mathrm{H}$-ras (Table II) sequences (21-23), and purified by gel electrophoresis before use. Oligonucleotide probes were $5^{\prime}$ end-labeled using $\left[\gamma^{32} \mathrm{P}\right]-$ ATP and polynucleotide kinase, then separated from unincorporated $\left[\gamma^{32}\right.$ P]ATP on Sep-Pak $C_{18}$ cartridges.
Table I. Sequences of Synthetic Oligonucleotides Used for K-ras PCR Amplimers and K-ras Normal and Mutant Allele-specific Probes

\section{K-ras amplimers}

EXON-1 (codon 12 and 13)

5'CCTGCTGAAAATGACTGAGTA 3' 3'CCTACTTATACTAGGATGCT 5'

EXON-2 (codon 59)

5'CTCCTACAGGAAACAAGTAG 3' 3TTAGTAAACTTCTATAAGTGG 5

K-ras probes

Codon 12 normal

K12 A

K12 B

K 12 C

K12 D

K12 E

$\mathrm{K} 12 \mathrm{~F}$

Codon 13 normal

K13 A

K13 B

K13 C

K13 D

K13 E

K13 F

Codon 59 normal

K59 A

K59 B

K59 C

K59 D

K59 E

K59 F
Gly Cys Ser Arg Val Asp Ala Gly Cys Ser Arg Val Asp

Ala

Ala

Ser

Pro

Thr

Gly

Val

Glu

PCR amplification of ras oncogene sequences. DNA was extracted from each rat colon specimen as described by Perucho et al. (24). A K-ras sequence of 116 bp including codons 12 and 13 of exon 1 , a 167-bp sequence from K-ras exon 2 including codons 59 and 61 , or a 68-bp sequence from $\mathrm{H}$-ras exon 1 including codons 12 and 13, were amplified in vitro by the polymerase chain reaction (PCR) using the oligonucleotide primers shown in Tables I and II. $1 \mu \mathrm{g}$ of DNA and 60 pmol of each of the relevant pair of amplimers were added to a 100- $\mu \mathrm{l}$ reaction mixture containing $2 \mathrm{U}$ of Taq polymerase (25). 30 cycles of denaturation $\left(94^{\circ} \mathrm{C}, 1 \mathrm{~min}\right)$, annealing $\left(55^{\circ} \mathrm{C}, 1 \mathrm{~min}\right)$, and extension $\left(72^{\circ} \mathrm{C}, 1.5 \mathrm{~min}\right)$ were conducted using an automated DNA thermal cycler (Perkin-Elmer Cetus), with a final 10-min extension after the last cycle. The absence of contamination was confirmed by analysis of PCR controls that had no added DNA. PCR products were analyzed by $4 \%$ agarose gel electrophoresis to ensure that adequate and approximately equal amounts of the expected size products were obtained, and that no contamination was present.

Oligonucleotide hybridization. Amplified DNA was applied to nitrocellulose membranes, which had been rinsed in deionized water and soaked in 20x SSC (standard saline citrate) using a Hybridot dot blot apparatus (Bethesda Research Laboratories, Gaithersburg, MD) or Minifold II slot blot device (Schleicher \& Schuell). PCR-amplified products were denatured for at least $15 \mathrm{~min}$ in $0.4 \mathrm{M} \mathrm{NaOH}, 25 \mathrm{mM}$ EDTA; then neutralized with $3 \mathrm{vol}$ of $1.5 \mathrm{M} \mathrm{NaCl}, 0.8 \mathrm{M}$ Tris, $\mathrm{pH} 7.8$, and immediately applied to the nitrocellulose filters. Each well was then rinsed with $20 \times$ SSC. DNA was immobilized on the nitrocellulose by baking at $80^{\circ} \mathrm{C}$ for $2 \mathrm{~h}$ in a vacuum oven. Filters were prehybridized at $37^{\circ} \mathrm{C}$ for at least $1 \mathrm{~h}$ in $5 \times \operatorname{SSPE}(1 \times \mathrm{SSPE}=180 \mathrm{mM} \mathrm{NaCl}, 10 \mathrm{mM}$ $\mathrm{NaH}_{2} \mathrm{PO}_{4}, 1$ mM EDTA, pH 7.4), $5 \times$ Denhardt's (1× Denhardt's $=200 \mathrm{mg} /$ liter each of polyvinylpyrrolidone, BSA, Ficoll 400 ), $1 \%$ SDS, $0.5 \%$ Carnation instant milk, $500 \mu \mathrm{g} / \mathrm{ml}$ sonicated denatured salmon sperm DNA. Hybridization at $37^{\circ} \mathrm{C}$ for $16 \mathrm{~h}$ was then done in a similar solution with the addition of a ${ }^{32} \mathrm{P}$-labeled oligonucleotide 
Table II. Sequences of Synthetic Oligonucleotides Used for H-ras PCR Amplimers and H-ras Normal and Mutant Allele-specific Probes

H-ras amplimers

EXON-1 (codon 12 and 13)

5'AAGCTTGTGGTGGTGGGCGC 3 '

3' TAGGTCGACTAGGTCTTGGT 5'

H-ras probes
H-ras normal
H12 A
H12 B
H12 C
H12 GAA
H12 GNA
H13 NGC
H13 GNC

5' GGC GCT GGA GGC GTG 3'
GGC GCT AGA GGC GTG
GGC GCT TGA GGC GTG
GGC GCT $\frac{\text { CGA GGC GTG }}{\text { GGC GCT GAA GGC GTG }}$
GGC GCT GNA GGC GTG
GGC GCT GGA NGC GTG
GGC GCT GGA GNC GTG

Gly
Arg
Stop
Arg
Glu
Gly, Glu, Ala, Val
Cys, Arg, Ser, Gly
Gly, Asp, Ala, Val

$N=\mathrm{A}, \mathrm{T}$, or $\mathrm{C}$

probe $\left(5 \mathrm{ng} / \mathrm{ml}\right.$; sp act $\left.10^{9} \mathrm{dpm} / \mu \mathrm{g}\right)$. The filters were rinsed in $6 \times \mathrm{SSC}$ $\left(1 \times \mathrm{SSC}=150 \mathrm{mM} \mathrm{NaCl}, 15 \mathrm{mM} \mathrm{Na}_{3}\right.$ citrate, $\mathrm{pH} \mathrm{7.0)}$ and washed twice for $30 \mathrm{~min}$ at $25^{\circ} \mathrm{C}$ in $6 \times \mathrm{SSC}$. The filters were then washed twice for $20 \mathrm{~min}$ at $25^{\circ} \mathrm{C}$ in $3 \mathrm{M}$ tetramethylammonium chloride, $50 \mathrm{mM}$ Tris, $2 \mathrm{mM}$ EDTA, $0.1 \%$ SDS, pH 8 (26); then washed $1 \mathrm{~h}$ at high stringency temperature $\left(58-60^{\circ} \mathrm{C}\right.$ for the 20 -mer oligonucleotides and $42-44^{\circ} \mathrm{C}$ for the 15 -mer probes). A sample was designated as containing a mutated ras sequence only if autoradiograms showed significant mutant probe binding to that amplified DNA after increasing the final wash temperature close to the melting temperature for that probe. Filters were autoradiographed using intensifier screens and Kodak XAR-5 film at $-70^{\circ} \mathrm{C}$ for $1-16 \mathrm{~h}$.

DNA sequencing. Mutations were confirmed by direct sequencing of amplified DNAs using the dideoxynucleotide chain termination method (27). PCR-amplified DNA was purified on anion-exchange - columns, extracted with isopropranol, and resuspended with a ${ }^{32} \mathrm{P}-\mathrm{la}$ beled antisense primer ( $5^{\prime}$ TCGTAGGATCATATTCATCC $\left.3^{\prime}\right)$ in $10 \mu$ l of $40 \mathrm{mM}$ Tris, $20 \mathrm{mM} \mathrm{MgCl}_{2}, 50 \mathrm{mM} \mathrm{NaCl}, \mathrm{pH}$ 7.5. The primer-template mixture was denatured for $3 \mathrm{~min}$ at $90^{\circ} \mathrm{C}$, annealed at $55^{\circ} \mathrm{C}$ for 15 min; then $1 \mu \mathrm{l}$ of $0.1 \mathrm{M}$ dithiothreitol and $1 \mu \mathrm{l}$ of a manganese buffer were added, before the addition of $2 U$ of Sequenase enzyme $(28,29)$. After transferring $3 \mu \mathrm{l}$ to each of four termination mixes, the solutions

Table III. Spectrum of K-ras Mutations in DMH-induced Colon Carcinomas
Tumors analyzed at $26 \mathrm{wk}$

Tumors with K-ras mutations

K-ras codon 12 GGT to GAT codon 13 GGC to GAC codon 59 GCA to ACA

\section{4}

29

20

8

1
$(66 \%)$

$(45 \%)$
37 male albino Sherman rats were injected with 1,2 dimethylhydrazine once per week until killing at $26 \mathrm{wk}$, and 44 colon carcinomas were obtained for analysis. K-ras sequences were amplified by PCR using DNA extracted from the tumors, then allele-specific oligonucleotide probe hybridization and DNA sequencing were used to determine whether point mutations activating the K-ras oncogene were present. were incubated at $37^{\circ} \mathrm{C}$ for $3 \mathrm{~min}$, electrophoresed on an $8 \%$ polyacrylamide-urea gel, and then autoradiographed.

\section{Results}

Specific $K$-ras oncogene $G$ to $A$ mutations are found in DMHinduced rat colon carcinomas. The spectrum of mutations induced by DMH had not previously been determined, therefore, we analyzed colon carcinoma DNAs to find which specific nucleotide substitutions were induced in ras genes by this carcinogen. 44 carcinomas and 20 histologically normal colonic mucosal specimens were obtained from 37 rats treated with carcinogen for $26 \mathrm{wk}$, and DNA was extracted from each. After PCR amplification of the relevant regions of exon 1 or exon 2 of either K-ras or H-ras as described in Methods, differential hybridization was done using radiolabeled oligonucleotide probes corresponding to the potential activating mutations in codons $12,13,59$, or 61 of the ras genes. $\mathrm{N}$-ras mutations were not analyzed because the rat $\mathrm{N}$-ras gene is not well characterized. No mutations were detected in the H-ras gene, but $66 \%$ of the carcinomas demonstrated mutations in K-ras as shown in Table III. All of the mutations were $G$ to $A$ transitions. Fig. 1 shows autoradiograms of dot blots demonstrating K-ras codon 12 GGT to GAT (Gly to Asp) mutations in 20 carcinomas (45\%), and codon 13 GGC to GAC (Gly to Asp) in 8 carcinomas (18\%). One carcinoma (blots not shown) had a K-ras codon 59 GCA to ACA (Ala to Thr) mutation. Dideoxynucleotide sequencing of the PCR-amplified DNA from the carcinomas with mutations was performed and confirmed the hybridization data (Fig. 2). In contrast to human colon cancer, no $\mathrm{G}$ to $\mathrm{T}$ or $\mathrm{G}$ to $\mathrm{C}$ mutations were found in the DMH carcinogen-induced tumors. This difference in mutation spectrum was significant at the $P<0.001$ level by chi-square analysis. The first nucleotide of codon 12 that is often mutated in human colon cancer $(3-5,7,8)$ is a guanine that presumably could be mutated to adenine by DMH as we found at other sites, but this type of mutation was not found in the $\mathbf{4 4}$ tumors examined.

$K$-ras mutations are detectable in histologically normal carcinogen-treated preneoplastic colonic mucosa. To determine whether K-ras mutation might be an early or possibly initiating 



Normal

K-Ras
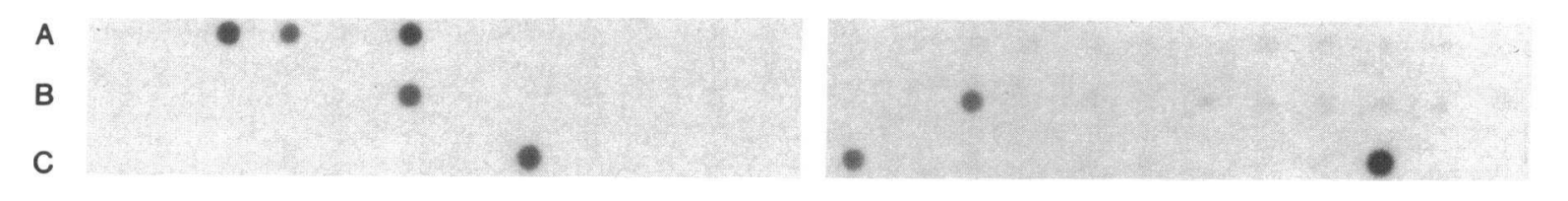

Codon

13 GAC


Codon

12 GAT
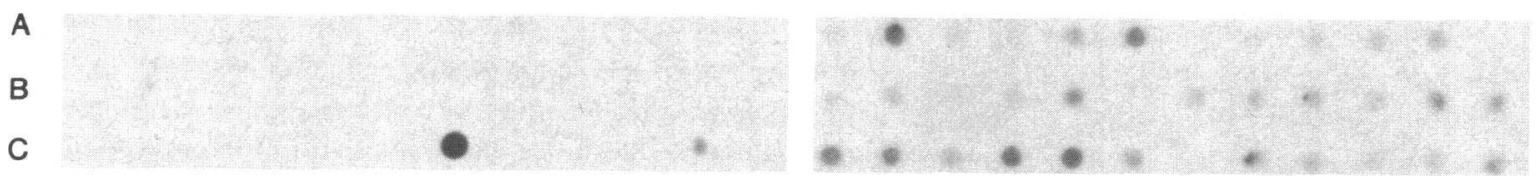

Codon

12 GTT

Figure 1. Characterization of K-ras codon 12 and codon 13 mutations in DMH carcinogen-induced rat colon carcinomas. DNAs extracted from tumors after $26 \mathrm{wk}$ of carcinogen treatment or from controls were amplified for K-ras exon 1 and spotted onto duplicate nitrocellulose filters, then analyzed by selective oligonucleotide hybridization to either normal K-ras probe or to probes specific for the 12 possible activating point mutations in codon 12 or 13 . Only the autoradiograms for probes demonstrating binding are shown. Controls included normal DNAs (B7, B19), DNA with a known codon $12 \mathrm{GTT} / \mathrm{Val}$ mutation from the SW480 human colon cancer cell line (C7), negative controls without any DNA added to the amplification to exclude PCR contamination (A7, A19, C12, C19), and DNAs extracted from uninvolved apparently normal areas of carcinogen-treated colonic mucosa (A8-A12, B8-B12, A20-A24, B20-B24). The remaining 44 spots represent rat colon carcinoma DNAs, 8 with codon $13 \mathrm{GAC}$ mutations and 20 with codon 12 GAT mutations.

event in carcinogenesis, colonic mucosa was analyzed at various time intervals after DMH treatment was begun, but before carcinomas developed. Colons obtained after 5,10 , or 15 wk of carcinogen treatment showed no evidence of dysplasia, adenomas, or carcinomas on microscopic examination of tissue sections. Ras mutations were detectable if more than 5\% of the cells analyzed in a tissue sample were affected, based on
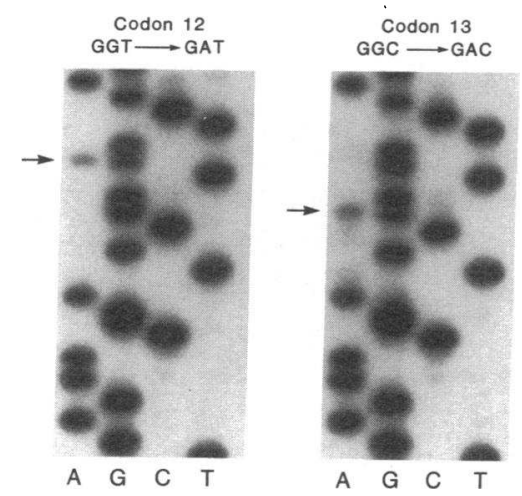

Figure 2. DNA sequencing to confirm DMH carcinogeninduced $\mathrm{G}$ to $\mathrm{A}$ mutations in K-ras codon 12 or codon 13 in rat colon carcinomas. DNAs extracted from colon carcinomas with codon 12 GGT to GAT or codon 13 GGC to GAC mutations as determined by selective oligonucleotide hybridization screening

(A6 and A17, respectively, from Fig. 1) were amplified for exon 1 of $\mathrm{K}$-ras and then sequenced by the dideoxynucleotide technique using an internal ${ }^{32} \mathrm{P}$-labeled antisense primer ( 5 ' TCG TAG GAT CAT ATT CAT CC $3^{\prime}$ ). The sequencing autoradiograms are labeled to indicate the coding (sense) sequence if read from top to bottom. Arrows indicate the positions of the mutated basepairs. the sensitivity of detection of known mutants in dilution series (data not shown). Mutations could not be detected after 5 ( $n$ $=8)$ or $10 \mathrm{wk}(n=19)$ of DMH treatment, but were detected using probe hybridization in 2 of 11 apparently normal samples of colonic mucosa obtained from two different rat colons

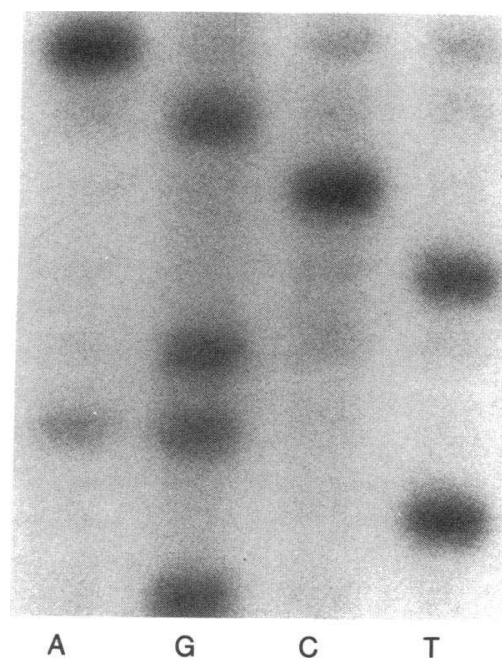

Figure 3. K-ras mutations of the type found in carcinomas at 26 wk can be demonstrated before tumor development in preneoplastic colonic mucosa after only 15 wk of carcinogen treatment. DNA was extracted from multiple small samples of apparently normal colonic mucosa after 15 wk of carcinogen treatment and screened for ras mutations by selective oligonucleotide hybridization. K-ras codon 12 GGT to GAT

mutations were found in two of these colonic mucosa DNAs and confirmed by DNA sequencing as shown in this autoradiogram, similar to those shown in Fig. 2. 
Table IV. K-ras Mutations Related to Size and Location of 26-Wk Colon Carcinomas

\begin{tabular}{|c|c|c|c|c|c|}
\hline \multirow{2}{*}{$\begin{array}{l}\text { Specimen } \\
\text { no. }\end{array}$} & \multirow{2}{*}{$\begin{array}{l}\text { Tumor } \\
\text { size"* }\end{array}$} & \multirow[b]{2}{*}{ Location ${ }^{*}$} & \multicolumn{3}{|c|}{ K-ras mutations } \\
\hline & & & Codon 12 & Codon 13 & Codon 59 \\
\hline 1 & 49 & 80 & $-A-$ & --- & --- \\
\hline 2 & 9 & 75 & $-A-$ & --- & --- \\
\hline 3 & 81 & 85 & $-A-$ & --- & --- \\
\hline 4 & 70 & 150 & $-A-$ & --- & --- \\
\hline 5 & 16 & 60 & $-A-$ & --- & --- \\
\hline 6 & 25 & 80 & $-\mathrm{A}-$ & --- & --- \\
\hline 7 & 12 & 150 & --- & --- & --- \\
\hline 8 & 4 & 60 & $-A-$ & --- & --- \\
\hline 9 & 4 & 65 & --- & $-\mathrm{A}-$ & --- \\
\hline 10 & 4 & 80 & $-A-$ & -- & --- \\
\hline 11 & 15 & 100 & $-\mathrm{A}-$ & --- & --- \\
\hline 12 & 4 & 80 & --- & --- & $A--$ \\
\hline 13 & 25 & 60 & --- & $-\mathrm{A}-$ & --- \\
\hline 14 & 15 & 70 & $-\mathrm{A}-$ & --- & --- \\
\hline 15 & 35 & 85 & --- & --- & --- \\
\hline 16 & 45 & 70 & --- & --- & --- \\
\hline 17 & 36 & 50 & $-\mathrm{A}-$ & --- & --- \\
\hline 18 & 16 & 65 & $-A-$ & -- & --- \\
\hline 19 & 36 & 65 & $-\mathrm{A}-$ & --- & --- \\
\hline 20 & 28 & 165 & $-\mathrm{A}-$ & --- & --- \\
\hline 21 & 12 & 30 & --- & $-\mathrm{A}-$ & --- \\
\hline 22 & 15 & 70 & --- & $-A-$ & --- \\
\hline 23 & 16 & 90 & --- & --- & --- \\
\hline 24 & 30 & 80 & --- & $-A-$ & --- \\
\hline 25 & 200 & 10 & --- & --- & --- \\
\hline 26 & 9 & 115 & $-\mathrm{A}-$ & --- & --- \\
\hline 27 & 12 & 195 & --- & --- & --- \\
\hline 28 & 16 & 160 & --- & -- & --- \\
\hline 29 & 25 & 20 & --- & --- & --- \\
\hline 30 & 30 & 85 & --- & $-\mathrm{A}-$ & --- \\
\hline 31 & 150 & 170 & --- & --- & --- \\
\hline 32 & 70 & 60 & --- & --- & --- \\
\hline 33 & 4 & 30 & $-A-$ & --- & --- \\
\hline 34 & 1 & 40 & --- & --- & --- \\
\hline 35 & 9 & 15 & $-A-$ & --- & --- \\
\hline 36 & 9 & 80 & --- & --- & --- \\
\hline 37 & 9 & 60 & --- & $-A-$ & --- \\
\hline 38 & 12 & 70 & $-\mathrm{A}-$ & --- & --- \\
\hline 39 & 6 & 15 & --- & --- & --- \\
\hline 40 & 16 & 85 & $-\mathrm{A}-$ & --- & --- \\
\hline 41 & 16 & 25 & --- & --- & --- \\
\hline 42 & 16 & 30 & --- & --- & --- \\
\hline 43 & 4 & 40 & --- & $-A-$ & --- \\
\hline 44 & 4 & 75 & $-\mathrm{A}-$ & --- & --- \\
\hline
\end{tabular}

* Tumor size in square millimeters of mucosal area involved.

* Tumor location in millimeters from the anus.

Dashes in the first, second, or third nucleotide positions indicate normal wild type sequence at those sites for codon 12 (GGT), codon 13 (GGC), or codon 59 (GCA). Mutations, which were all $G$ to $A$ transitions, are indicated by an $\mathrm{A}$ at the mutated site.

after 15 wk of carcinogen treatment, a finding confirmed by DNA sequencing (Fig. 3). The mutations found, codon 12 GGT to GAT in both cases, are the same type as seen in the majority of carcinomas after 26 wk of DMH treatment.
$K$-ras mutation rate correlates with tumor size. The location of each colon tumor (distance in millimeters from the anus) and tumor size (mucosal area in square millimeters) were recorded at the time of killing of each rat, and these data are related to the type of K-ras mutation in Table IV. The majority of carcinomas in this rat strain are located in the distal colon, comparable to the distribution of sporadic colon cancers in humans (16). Distal colon carcinomas (0-100 $\mathrm{mm}$ from anus) had a $\mathrm{K}$-ras mutation rate of $70 \%$, in contrast to only $43 \%$ in proximal colon carcinomas; however, these differences did not reach statistical significance $(P>0.05)$.

The presence of ras mutations might be expected to increase tumor growth rate (7) and therefore correlate with larger tumor size, but our results show the opposite. Tumors without ras mutation were larger, $42 \pm 17 \mathrm{~mm}^{2}(n=15)$ vs. $20.4 \pm 3.8$ $\mathrm{mm}^{2}(n=29)$ for tumors with mutated K-ras sequences $(P$ $<0.05)$. All tumors $>100 \mathrm{~mm}^{2}$ in area lacked ras mutation $(P$ $<0.05$ by chi-square analysis).

Tumors from rats with multiple carcinomas had a higher incidence of ras mutation with $76 \%$ of the tumors mutated if three or more tumors were present, $57 \%$ mutated if two tumors were present, and $25 \%$ mutated if there was only one tumor per rat. Nine rats had multiple tumors with different K-ras sequences in tumors from the same rat, indicating that the ras mutations occurred as independent events.

\section{Discussion}

These experiments demonstrate for the first time that approximately two-thirds of DMH-induced colonic tumors have detectable K-ras mutations, and these are all $\mathrm{G}$ to $\mathrm{A}$ transitions. Moreover, similar mutations were also detected in the preneoplastic colonic tissue of animals treated with this carcinogen, albeit at a lower rate.

While it therefore appears that both sporadic human cancers and DMH-induced tumors have a high incidence of K-ras mutations, it should be noted that the K-ras mutations seen in colonic malignancies in this model differ from their human counterparts in several respects. Thus, the DMH-induced colonic mutations were exclusively $G$ to $A$ transitions, while sporadic human colonic tumor $\mathrm{K}$-ras mutations exhibit $\mathrm{A}, \mathrm{T}$, or $\mathrm{C}$ substitutions at either the first or second nucleotides of $\mathrm{K}-$ ras codon $12(3-5,7,8)$. There was an interesting positional bias in DMH mutations with the second nucleotide of codon 12 mutated two and one-half times as often as the second nucleotide of codon 13, and codon 59 mutations occurring rarely. Although $\mathrm{G}$ to $\mathrm{A}$ mutations of the first nucleotide of codon 12 are frequent in sporadic human colon cancers (3-5, 7,8 ), and we found $G$ to $A$ mutations induced by DMH at other sites, mutation at this position was not observed. Further studies will be necessary to determine what factors influence the sites of modification by DMH and other chemical carcinogens.

Our data suggest that K-ras point mutations are an important but not obligatory event in the development of experimental colon carcinomas. H-ras mutations were not observed at codon 12 or 13 . However, since possible H-ras codon 61 and $\mathrm{N}$-ras mutations were not analyzed, we cannot exclude the possibility that these latter mutations occurred among the $34 \%$ of tumors that lacked K-ras mutation. In addition, alteration of genes not included in the ras family may substitute for the 
effect of ras activation. Thus, the observed incidence of ras activation in a particular system may be determined by the balance between the ras mutation rate and the susceptibility to mutation by particular carcinogens of these other, as yet unknown, genes. The genetic alterations that are an alternative to $\mathrm{K}$-ras mutation may have a different phenotypic effect since the one-third of tumors lacking K-ras mutation in this model were significantly larger. This phenomenon may be less easily observed in human tumors than in our animal model where neoplasms develop as a relatively synchronized cohort, carcinogen administration begins simultaneously, initiating mutations occur over a short time interval, and each animal, since inbred, has an identical genetic background. In this system, therefore, we may have been able to detect subtle differences in biological behavior resulting from the activation of alternative molecular genetic pathways of tumor progression.

DMH-induced carcinomas in the present experiments, like spontaneous human colon cancers, were located primarily in the distal rather than the proximal colon. Genetic alterations, including allele losses on human chromosomes 5, 17, and 18, were recently reported as more frequent in distal than in proximal human colon carcinomas (30). K-ras mutation rates in these human tumors, however, were not found to be significantly different in the proximal $(41 \%)$ and distal $(54 \%)$ regions of the colon (30); a finding also noted in this study (proximal, $43 \%$; distal $70 \% ; P>0.05$ ). The factors influencing the location of carcinomas in the colon are not well understood, although stasis of fecal matter in the distal sigmoid and rectum may allow more prolonged contact with potential carcinogens or promoters. Genetic factors may at times favor more proximal colon carcinomas as seen in patients with the hereditary nonpolyposis Lynch syndrome (31).

Ras mutations have been implicated as early events in the malignant transformation process in many studies (6), but controversy still exists regarding the timing of these mutations in a multistep model of colon carcinogenesis. For example, while $\mathrm{K}$-ras mutations have been found in human adenomatous polyps $>1 \mathrm{~cm}$ in size in approximately the same frequency as in the carcinomas, such mutations have been identified in only $9 \%$ of adenomas $<1 \mathrm{~cm}$ in size (3). In a few cases, identical ras mutations have also been demonstrated both in the carcinoma and adjacent adenomatous tissue from which that carcinoma presumably developed (5). Although these earlier studies implied that ras mutations may occur early in the formation of adenomas, the occurrence of these mutations in preneoplastic colonic mucosa has not previously been described. We detected K-ras mutations, of the same type as later found in carcinomas, in histopathologically normal colonic mucosa after only 15 wk of DMH injection. This latter finding would strongly support previous contentions that ras mutations may indeed be an early or initiating event in colonic carcinogenesis in at least some cases. However, the progression of neoplastic development induced by DMH in the rat colon differs somewhat from the typical progression postulated in humans, since adenomas are relatively rare in this experimental model and many carcinomas arise de novo from flat mucosa (32). Additionally, we cannot totally exclude the possibility that microscopic foci of carcinomatous cells were present in the apparently normal colonic mucosa at $15 \mathrm{wk}$ and may account for the K-ras mutations observed in two colons.

Finally, as noted earlier, animal models, such as the one used in these studies, have distinct advantages including: (a) preneoplastic tissue can be obtained; $(b)$ tumors develop as a relatively synchronized cohort; and $(c)$ factors possibly influencing genetic alterations and malignant progression can be manipulated and controlled. Future studies, using the DMH model to explore the possible relationship between other genetic alterations and their role in colonic malignant transformation, will, therefore, be of interest and are currently being conducted in our laboratory.

\section{Acknowledgments}

The authors thank Carol Westbrook for providing several oligonucleotides and helpful advice. We also thank Lynn Nelson for excellent secretarial support.

This investigation was supported by National Cancer Institute grant CA-36745, by Digestive Disease Center grant DK-42086, and by National Institutes of Health grants HL-38180 and K04-HL-02166. T. A. Brasitus is a recipient of a Merit Award and R. F. Jacoby is a recipient of an NRSA fellowship award from the National Cancer Institute. These studies were also supported by the Samuel Freedman Laboratories for Gastrointestinal Cancer Research.

\section{References}

1. Maskens, A. P. 1983. Mechanisms of colorectal carcinogenesis in animal models: possible implications in cancer prevention. In Precancerous Lesions of the Gastrointestinal Tract. P. Therlock, B. C. Morson, L. Barbana, and U. Veronesi, editors. Raven Press, Ltd., New York. 223-235.

2. Weinberg, R. A. 1989. Oncogenes, antioncogenes, and the molecular basis of multistep carcinogenesis. Cancer Res. 49:3713-3721.

3. Fogelstein, B, E. R. Fearon, S. R. Hamilton, S. E. Kern, A. C. Preisinger, M. Leppert, Y. Nakamura, R. White, A. M. M. Smits, and J. L. Bos. 1988. Genetic alterations during colorectal-tumor development. N. Engl. J. Med. 319:525-532.

4. Forrester, K., C. Almoguera, K. Itan, W. E. Grizzle, and M. Perucho. 1987. Detection of high incidence of K-ras oncogenes during human colon tumorigenesis. Nature (Lond.). 327:298-303.

5. Bos, J. L., E. R. Fearon, S. R. Hamilton, M. Verlaan-deVries, J. H. vanBoom, A. J. vander Eb, and B. Vogelstein. 1987. Prevalence of ras gene mutations in human colorectal cancers. Nature (Lond.). 327:293-297.

6. Barbacid, M. 1987. ras genes. Annu. Rev. Biochem. 56:779-827.

7. Bos, J. L. 1989. Ras oncogenes in human cancer: a review. Cancer Res. 49:4682-4689.

8. Burmer, G. C., and L. A. Loeb. 1989. Mutations in the KRAS2 oncogene during progressive stages of human colon carcinoma. Proc. Natl. Acad. Sci. USA. 86:2403-2407.

9. Sukumar, S., V. Notario, D. Martin-Zanca, and M. Barbacid. 1983. Induction of mammary carcinomas in rats by nitroso-methylurea involves malignant activation of H-ras-1 locus by single point mutations. Nature (Lond.). 306:658661 .

10. Zarbl, H., S. Sukumar, A. V. Arthur, D. M. Zanca, and M. Barbacid. 1985. Direct mutagenesis of Ha-ras-1 oncogenes by N-nitroso-N-methylurea during initiation of mammary carcinogenesis in rats. Nature (Lond.). 315:382-385.

11. Pegg A. E. 1984. Methylation of the $\mathrm{O}^{6}$ position of guanine in DNA is the most likely initiating event in carcinogenesis by methylating agents. Cancer Invest. $2: 223-231$.

12. Mitra, G., G. T. Pauly, R. Kumar, G. K. Pei, S. H. Hughes, R. C. Moschel, and M. Barbacid. 1989. Molecular analysis of $\mathrm{O}^{6}$-substituted guanine-induced mutagenesis of ras oncogenes. Proc. Natl. Acad. Sci. USA. 86:8650-8654.

13. Topal, M. D. 1988. DNA repair, oncogenes and carcinogenesis. Carcinogenesis (Lond.). 9:691-696.

14. Thurnherr, N., E. E. Deschner, E. H. Stonehill, and M. Lipkin. 1973. Induction of adenocarcinomas of the colon in mice by weekly injections of DMH. Cancer Res. 33:940-945.

15. Ahnen, D. J. 1985. Are animal models of colon cancer relevant to human diseases? Dig. Dis. Sci. 30(12):103S-106S.

16. LaMont, J. L., and T. A. O'Gorman. 1978. Experimental colon cancer. Gastroenterology. 75:1157-1169.

17. Freeman, H. J., Y. Kim, and Y. S. Kim. 1978. Glycoprotein metabolism in normal proximal and distal rat colon and changes associated with 1,2 dimethylhydrazine induced colonic neoplasia. Cancer Res. 39:3385-3390. 
18. Ward, J. M. 1974. Morphogenesis of chemically induced neoplasmas of the colon and small intestine in rats. Lab Invest. 30:505-513.

19. Caignard, A., Y. Kitagawa, S. Sato, and M. Nagao. 1988. Activated K-ras in tumorigenic and non-tumorigenic cell variants from a rat colon adenocarcinoma induced by dimethylhydrazine. Cancer Res. 79:244-249.

20. Barkla, D. H., and P. J. M. Tutton. 1978. Ultrastructure of 1,2 dimethylhydrazine-induced adenocarcinomas in rat colon. J. Natl. Cancer Inst. (Bethesda). 61:1291-1299.

21. George, D. L., A. F. Scott, S. Trusko, B. Glick, E. Ford, and P. J. Dorney. 1985. Structure and expression of amplified cKi-ras gene sequences in $Y 1$ mouse adrenal tumor cells. EMBO (Eur. Mol. Biol. Organ.) J. 4:1199-1203.

22. Ruta, M., R. Wolford, R. Dhar, D. Defeo-Jones, R. W. Ellis, and E. M. Scolnick. 1986. Nucleotide sequence of the two rat cellular ras $\mathrm{H}$ genes. $\mathrm{Mol}$. Cell. Biol. 6:1706-1710.

23. Tahira, T., et al. 1986. Structure of the c-ki-ras gene in a rat fibrosarcoma induced by 1,8-dinitropyrene. Mol. Cell Biol. 6:1349-1351.

24. Perucho, M., M. Goldfarb, K. Shimizu, C. Lama, J. Fough, and M. Wigler. 1981. Human-tumor-derived cell lines contain common and differen transforming genes. Cell. 27:467-476.

25. Saiki, R. K., O. H. Gelfand, S. Stoffel, S. J. Sharf, R. Higuchi, G. T. Horn,
K. B. Mullis, and H. A. Erlich. 1988. Primer-directed enzymatic amplification of DNA with a thermostable DNA polymerase. Science (Wash. DC). 239:487-491.

26. Wood, W. I., J. Gitschier, L. A. Lasky, and R. M. Lawn. 1985. Base composition-independent hybridization in tetramethylammonium chloride: a method for oligonucleotide screening of highly complex gene libraries. Proc. Natl. Acad. Sci. USA. 82:1585-1588.

27. Sanger, F. S Miklen, and A. R Coulson. 1977. DNA sequencing with chain-terminating inhibitors. Proc. Natl. Acad. Sci. USA. 4:5463-5467.

28. Tabor, S., and C. C. Richardson. 1989. Effect of manganese ions on the incorporation of dideoxynucleotides by bacteriophage $T_{7}$ DNA polymerase and Escherichia coli DNA polymerase I. Proc. Natl. Acad. Sci. USA. 86:4076-4080.

29. Tabor, S., and C. C. Richardson. 1989. Selective inactivation of the exonuclease activity of bacteriophage $T_{7}$ DNA polymerase by in vitro mutagenesis. $J$. Biol. Chem. 264:6447-6458.

30. Delattre, O., D. J. Law, Y. Remvikos, X. Sastre, S. Olschwang, T. Melot, R. J. Salmon, P. Validire, and G. Thomas. 1989. Multiple genetic alterations in distal and proximal colorectal cancer. Lancet. ii:353-355.

31. Lynch, P. M., H. T. Lynch, and R. E. Harris. 1977. Hereditary proximal colonic cancer. Dis. Colon Rectum. 20:661-668.

32. Maskens, A., and R. Dujardin-Loits. 1981. Experimental adenomas and carcinomas or the large intestine behave as distinct entities: most carcinomas arise de novo in flat mucosa. Cancer (Phila.). 47:81-89. 